\title{
NÃO HÁ MAL QUE SEMPRE DURE
}

Há quatro anos, uma mulher brilhante, culta e altiva, jurista e política experiente e propositiva, Hillary Clinton, foi derrotada no colégio eleitoral estado-unidense (mesmo vitoriosa na totalização dos votos de cidadãos eleitores que participaram deste processo obsoleto se comparado com o das melhores Democracias do planeta Terra). Aceitável, face às regras vigentes, mas trágico pelo vencedor ter sido, ao longo de seu mandato, um nacionalista retrógrado em tempos de saudável globalização, um revisionista da História e um desrespeitador da Ciência (e de nossas inteligências: emocional, política e ética).

Conseguiu até mesmo obter o apoio incondicional de um Presidente, no maior país da América do Sul, onde se tentam reconstruir Casas Grandes e Senzalas. Infelizmente, o Presidente, que se diz verde e amarelo, tudo concedeu ao estado-unidense, enquanto nós brasileiros (assim como nosso amado Brasil) nada recebemos em troca, seja no aspecto político e, principalmente, nos aspectos econômico e social.

O mais promissor da mudança de mãos do poder estado-unidense é dar a nós Brasileiros, pelo exemplo que estamos testemunhando, perspectivas mais animadoras de também podermos reconstruir o que tem sido destruído em termos de Ecologia, respeito às minorias, à diversidade, à Cultura, à História e à Ciência.

Tenho muito orgulho de minha formação em Ética e Bioética em USA (Kennedy Institute; Georgetown University; Washington).

Considerando este excelente período de convívio acadêmico e formação especializada, justifico meus votos para que USA retornem ao pleno e necessário convívio com organismos internacionais, assim como às iniciativas meritórias para a qualidade de vida no planeta Terra como, por exemplo, o importantíssimo Acordo do Clima.

Que o obscurantismo, a truculência, o desprezo às divergências e a exposição vexatória constante ao mundo civilizado dêem lugar à luz, à razão e a uma religiosidade de coração e de alma, com pluralidade e veracidade.

Já no Brasil, na esteira destes ares agora despoluídos, resta-nos agradecer a quem está dedicado ao melhor atendimento possível de doentes em unidades de saúde ambulatoriais e hospitalares (mesmo face a políticas federais equivocadas no enfrentamento à Pandemia COVID-19); aos que produzem e transportam alimentos, gêneros de higiene e limpeza, medicamentos, equipamentos e combustíveis; aos que coletam e reciclam lixo; aos que mantém atividades econômicas e jurídicas; aos que pesquisam e divulgam notícias verdadeiras; aos que trabalham por nossa segurança, assim como na manutenção de energia, água potável, internet e socorro às vítimas de acidentes e intempéries.

Mulheres e homens com um mínimo de humanismo e civilidade e que, em pleno século XXI, valorizam Ciência e Cultura, continuarão a luta cidadã para que, o que ainda resta de bom em nosso amado Brasil, possa sobreviver, mantendo-se a dignidade e o respeito indispensáveis ao convívio dos justos.

Nada de bom se constrói para uma Sociedade Humana onde ainda vicejam a ignorância manipulada e o analfabetismo que castra o acesso à informação de qualidade e que dificulta o amadurecimento da Cidadania. 
Acredito ser imperioso começar a se refletir e a planejar criteriosamente nosso próximo voto, para que o processo eleitoral possa nos conduzir a governantes concretamente capazes de não apenas acenar com, mas verdadeiramente realizar, de forma célere e comprometida, enquanto PRIORIDADE NACIONAL, ações coordenadas que propiciem, na prática e a curto prazo, instalação e adequação de escolas civis públicas de qualidade para crianças e jovens, com recursos humanos e materiais necessários, além do imediato pagamento de piso nacional DIGNO para todos os profissionais de EDUCAÇÃO, desde a pré-escola.

Fundamental será resgatar a Autonomia Universitária assim como reestabelecer o RESPEITO a processos e procedimentos de Universidades Públicas, centros brasileiros de excelência científica e cultural, objetiva e tradicionalmente formadoras de profissionais qualificados para o atendimento das necessidades das comunidades, consequentes para a vida das PESSOAS e promotoras de importantes Pesquisas, muitas integradas aos melhores Grupos de Inovação mundiais.

Nosso Brasil somente evoluirá como NAÇÃO quando este tempo de LUZ sobre as trevas chegar: Escola Pública de qualidade em todos os níveis.

Marilia Gerhardt de Oliveira

Especialista e Mestre em CTBMF

Doutora em Estomatologia Clínica

Membro Titular AcBO - cadeira 77

CTBMF do HCR-GHC do MS - Brasil

gerhardtoliveira@gmail.com 